\title{
Readability of packaging of medicinal products available without prescription as assessed by older consumers \\ Katarzyna Grzybek
}

M.Sc., Doctoral School of the University of Economics in Krakow, Major: Quality and Product Management, Poland. "The publication was co-financed by the subsidy granted to the University of Economics in Krakow"

Email: katarzynawasek93@gmail.com

Keywords

OTC Drugs, Senior, Consumer, Packaging, Legibility, Information.

\section{Article History}

Received on $18^{\text {th }}$ August 2021

Accepted on $31^{\text {st }}$ August 2021

Published on $4^{\text {th }}$ September 2021

\section{Cite this article}

Grzybek, K. (2021). Readability of packaging of medicinal products available without prescription as assessed by older consumers. Humanities \& Social Sciences Reviews, 9(5), 08-14.

https://doi.org/10.18510/hssr.2021.952

Copyright @ Author

Publishing License

This work is licensed under a Creative Commons Attribution-Share Alike 4.0 International License

\section{Abstract}

The labeling of the medicinal product packaging plays an important role in communication between entities placing the product on the market and its potential buyers. Moreover, the correct labeling of the packaging can protect the life and health of patient consumers. Due to the above, the labeling of the packaging of a medicinal product is subject to numerous legal regulations and has become the subject of consideration of many scientists.

The aim of the article is to present the results of research on the readability of the packaging of over-the-counter medicinal products as assessed by older consumers. The research was carried out using a questionnaire throughout Poland. 400 respondents took part in the survey aged 60 and over. 


\section{Czytelność opakowań produktów leczniczych dostępnych bez recepty w ocenie starszych konsumentów Katarzyna Grzybek}

Mgr inż., Szkoła Doktorska Uniwersytetu Ekonomicznego w Krakowie, kierunek: Jakość i Zarządzanie Produktem „Publikacja została dofinansowana ze środków subwencji przyznanej Uniwersytetowi Ekonomicznemu w Krakowie”

E-mail: katarzynawasek93@gmail.com

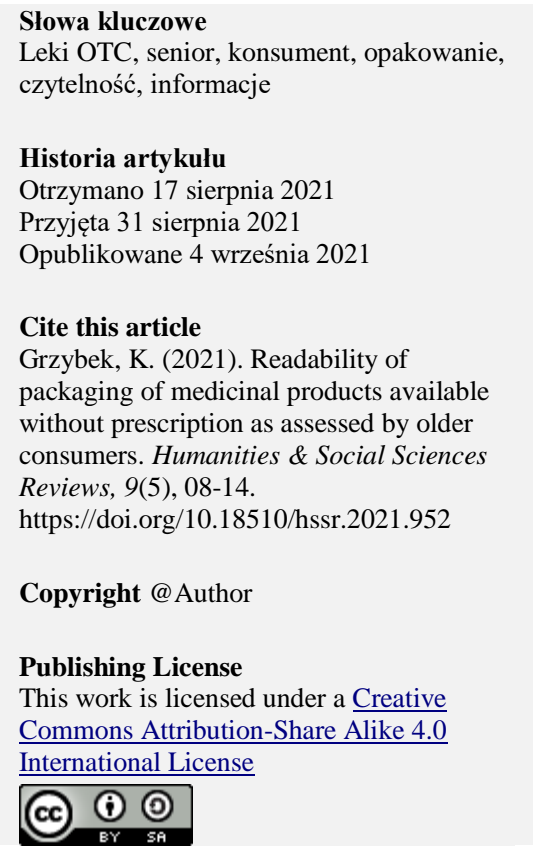

\section{Streszczenie}

Oznakowanie opakowania produktu leczniczego pełni istotną rolę w komunikacji pomiędzy podmiotami wprowadzającymi produkt na rynek a jego potencjalnymi nabywcami. Co więcej, prawidłowe oznakowanie opakowania może wpływać na ochronę życia i zdrowia konsumentów-pacjentów. Ze względu na powyższe etykietowanie opakowania produktu leczniczego podlega licznym regulacjom prawnym oraz stało się przedmiotem rozważań wielu naukowców.

Celem artykułu jest przedstawienie wyników badań dotyczących czytelności opakowań produktów leczniczych dostępnych bez recepty w ocenie starszych konsumentów. Badania przeprowadzone zostały za pomocą kwestionariusza ankietowego na terenie całej Polski. W badaniu wzięło udział 400 respondentów w wieku 60 lat i powyżej.

\section{Wstęp}

Opakowanie pełni istotną rolę w komunikacji pomiędzy podmiotami wprowadzającymi produkt na rynek a ich potencjalnymi nabywcami. Jego rola jest szczególnie istotna w systemie sprzedaży samoobsługowej. Etykietowanie produktu pozwala na przedstawienie podstawowych informacji oraz obligatoryjnych danych dotyczących produktu, normowanych odpowiednimi przepisami prawnymi -Śmiechowska (2010).

Prawidłowe oznakowanie jest szczególnie znaczące w odniesieniu do produktów leczniczych, może ono wpływać bowiem na ochronę życia i zdrowia pacjentów. Produkt leczniczy w myśl Ustawy z dnia 6 września 2001, Prawo farmaceutyczne jest to: „substancja lub mieszanina substancji, przedstawiana jako posiadająca właściwości zapobiegania lub leczenia chorób występujących u ludzi lub zwierząt lub podawana w celu postawienia diagnozy lub w celu przywrócenia, poprawienia lub modyfikacji fizjologicznych funkcji organizmu poprzez działanie farmakologiczne, immunologiczne lub metaboliczne" (Ustawa z dnia 6 września 2001 r... Dz. U. $2001 \mathrm{Nr} 126$ poz. 1381 z póź.zm.).

Znaki zawierane na opakowaniach leków podlegają ścisłym restrykcjom ze strony państwa. Podstawowym aktem prawnym normującym kwestię informacyjności opakowań produktów leczniczych są: Ustawa z dnia 6 września 2001r. Prawo farmaceutyczne z późniejszymi zmianami, Rozporządzenie Ministra Zdrowia z dnia 20 lutego 2009r. w sprawie wymagań dotyczących oznakowania opakowań produktu leczniczego i treści ulotki z późniejszymi zmianami oraz Rozporządzenie Ministra Zdrowia z dnia 26 kwietnia 2010r. w sprawie badania czytelności ulotki. Regulacje te odnoszą się do wszystkich 3 elementów opakowania produktów leków tzn. opakowania zewnętrznego, bezpośredniego oraz ulotki.

Seniorzy są bardzo ważną grupą docelową na rynku farmaceutycznym. Według danych pochodzących z raportu Narodowego Funduszu Zdrowia (NFZ o polipragmazji 2020) aż 1/3 Polaków po 65 roku życia (16,5 mln) przyjmuje przynajmniej

5 różnych leków dziennie.

Z kolei 62,8tys. Pacjentów przyjmowało choć w jednym miesiącu w roku 10 lub więcej substancji przez $80 \%$ dni w miesiącu. Wyniki te zostały potwierdzone w badaniach przeprowadzonych przez Rajska-Neumann A. i in. (2012). Dowodzą one, iż co najmniej 5 leków dziennie zażywa 55\% badanych, co najmniej 10 leków zażywa 11\% ankietowanych. Co ciekawe przebadane pod tym względem zostały również osoby z tzw. wieku przedemerytalnego, czyli 55-59lat. W młodszej grupie konsumentów jedynie $24 \%$ badanych zażywa co najmniej 5 leków dziennie, a zażywanie minimum 10 leków zadeklarowało jedynie $2 \%$ uczestników badania. 
Seniorzy stanowią wyjątkową grupę konsumentów również ze względu na fakt, że proces starzenia się ma znaczący wpływ na zmianę wzorców konsumpcji, nawyków zakupowych oraz percepcję produktów opakowanych. Prace naukowe autorstwa Świtały (2011) dowodzą, że wraz z wiekiem zachodzą zmiany w zakresie inteligencji płynnej. Ponadto następuje również pogorszenie funkcji poznawczych, co w znaczący sposób wpływa na ograniczenie ilości i jakości informacji dostarczanych z zewnątrz. Niezgoda i Jerzyk (2013) w swych badaniach potwierdzili, iż aktywność poznawcza osób w wieku $60+$ jest średnio o 30\% niższa niż u osób młodych. Powoduje to zmniejszenie umiejętności zbierania i przetwarzania nowych informacji. Proces starzenia się jest procesem indywidualnym, stąd seniorzy stanowią grupę konsumencką silnie heterogeniczną.

Celem podjętych badań naukowych była weryfikacja zwyczajów oraz trudności seniorów w zakresie czytelności opakowań produktów leczniczych dostępnych bez recepty.

\section{Przegląd literatury przedmiotu}

Zachowania i zwyczaje konsumentów w wieku senioralnym związane z zakupem i użytkowaniem produktów leczniczych zostały przeanalizowane m.in. przez badaczy takich jak: Fraeyman i in. (2015), Cybulski i in. (2018) oraz Grzybek (2020). Analiza wyników badań prezentowanych w ww. pracach wskazuje m.in., iż osoby starsze angażują się w zakup leków OTC bardziej niż młodsze pokolenia, a kupowane przez nich produkty lecznicze przeznaczone są na własny użytek. Zdaniem starszych konsumentów produkty tego rodzaju powinny być sprzedawane wyłącznie w aptekach. Fraeyman i in. (2015), wykazał duże przywiązanie do marki seniorów oraz brak orientacji w rynku leków generycznych.

Szczegółowe badania uwzględniające tematykę wpływu opakowania na decyzje zakupowe starszych konsumentów uwzględniające możliwości zapamiętywania przez nich określonych treści oraz grafiki umieszczanej na opakowaniach przeprowadził Pradeep (2011). Analiza uzyskanych wyników potwierdziła zasadność ograniczenia elementów grafiki oraz zdobnictwa liter na opakowaniach dedykowanych dla osób starszych. Według autora nadmiar tych elementów może wpływać niekorzystnie na zdolność odczytania oraz zrozumienia informacji przez osoby starsze. Badania Pradeepa stały się podstawą do zgłębienia problematyki oceny informacyjności opakowań. Dalsze badania nad oceną czytelności opakowań przez osoby starsze prowadzili m.in. Świda i Migdała-Warchol (2016), Byłeń (2016), Droulers i Amar (2016), Caban-Piaskowska i Miarka (2018). Uzyskane wyniki badań potwierdziły, że rodzaj i wielkość czcionki informacji umieszczonych na opakowaniach mogą istotnie wpłynąć na zrozumieniem informacji przez seniorów i wpłynąć na ich decyzje zakupowe.

Jak dowodzą naukowcy Oeser i in. (2019) starsi konsumenci wyżej oceniają wiarygodność produktu, gdy informacje zawarte na jego opakowaniu są dla nich zrozumiałe. Według Stroud (2005), Szepieniec-Puchalskej i Szymańskiej (2016), brak czytelności informacji zawartych na opakowaniach produktów połączona z większą trudnością ich przetwarzania przez seniorów może prowadzić do niechęci starszych konsumentów i rezygnacji z sięgania po nowe produkty oraz umocnienia postawy lojalnościowej wobec znanych marek.

Zagadnienia dotyczące analizy świadomości starszych konsumentów w zakresie informacyjności opakowań produktów leczniczych podejmowane były również przez takich autorów jak: Liu i in. (2014), Grzybek (2020) opierając się na założeniu, że ulotki informacyjne dla pacjentów są jednym z ważniejszych źródłem informacji dla starszych pacjentów, umożliwiającym skuteczne zarządzanie farmakoterapią, przeprowadzili badania nad czytelnością informacji zawartych na opakowaniach produktów leczniczych. Badania dowiodły, że spośród badanych ok. 10\% seniorów nie potrafiło odczytać informacji zamieszczonych na etykiecie, a blisko $67 \%$ nie było wstanie zinterpretować umieszczonych informacji. Z kolei Liu i in. (2014) przeprowadził ocenę czytelności informacji zawartych na etykietach produktów leczniczych $z$ wykorzystaniem tzw. indeksu czytelności Foga (ang. Gunning Fog Index), który ma na celu określenie stopnia przystępności tekstu dla odbiorcy. Uzyskane wyniki badań wykazały, że tekst zawarty w ulotce jest trudny do zrozumienia dla osób starszych z powodu zbyt małej zastosowanej czcionki. Badania nad czytelnością ulotek produktów leczniczych występujących na rynku amerykańskim, prowadzone były również przez Chubaty i in. (2009). Jak wykazały wyniki badań, tylko w przypadku jednej trzeciej wszystkich ulotek zastosowana była minimalna zalecana wielkość liter. Ponadto niespełna $20 \%$ firm farmaceutycznych zastosowało w swych ulotkach wymagane przez amerykańskie prawo odstępy między wierszami (1,5 wiersza). Natomiast w przypadku ponad 77\% ulotek został zastosowany właściwy kontrast pomiędzy tłem a czcionką. Badania nad czytelnością ulotki były również prowadzone na rynku irlandzkim przez O’Sullivan i in. (2020), którzy wskazali, że projekty standardowych czcionek wykorzystanych w ulotkach dla seniorów powinny uwzględniać wysoki kontrast między ciemnymi i jasnymi elementami oraz wielkość punktów powinna być również większa niż 12. Ponadto ulotka powinna zawierać szczegółowe informacje dla osób starszych (np. informacje o interakcjach leków w starszej generacji). Wyniki tych badań znalazły potwierdzenie również w pracach Isaacs i in. (2020), którzy dokonali analizy tekstów ulotek informacyjnych za pomocą narzędzia obliczeniowego Coh-Metrix. Przeprowadzona analiza ujawniła różne wymiary językowe związane ze złożonością dokumentów i wskazała na problem użycia w ulotkach specjalistycznej nomenklatury medycznej, mało zrozumiałej dla seniorów, która powoduje zwiększenie obciążenia poznawczego pacjentów podczas czytania tekstu.

Podobne wnioski zostały również sformułowane przez Mamen i in. (2015) Karapinar-Çarkit i in. (2020). Wyniki badań przeprowadzonych wśród holenderskich seniorów potwierdziły również problemy $\mathrm{z}$ czytelnością informacji na opakowaniach produktów leczniczych u ponad 60\% seniorów. Ponadto Autorzy zwrócili uwagę na zbyt skomplikowane instrukcje użytkowania, powodujące kłopoty interpretacyjne w grupie użytkowników. Z kolei Da Silva i in. (2019) przeprowadzili eksperyment, który pozwolił na zaproponowanie rozwiązań w zakresie zwiększenia czytelności informacji 
na opakowaniach produktów leczniczych, polegający na zwiększeniu rozmiaru czcionki tekstu, uwypukleniu wskazań i przeciwskazań stosowania leku oraz podkreślenie daty ważności. Wprowadzenie tych zmian zwiększyłoby czytelność informacji o ok. 95,4\%. Podobne wnioski zostały również sformułowane przez Lisińską-Kuśnierz i Grzybek (2019).

Przywołane wyniki badań stanowią o istotnej roli oznakowania opakowania i jego czytelności w zakresie zaspokajania potrzeb osób starszych. Przedstawione prace w większości dotyczą analizy możliwości odczytania informacji przez seniora oraz preferencji starszych konsumentów w tym zakresie. Autorskie badania przedstawione w niniejszej pracy stanowią o poszczególnych elementach oznakowania stanowiących trudność w czytelności opakowań. Identyfikacja problemów z odczytaniem informacji przez starszego konsumenta miała charakter deklaratywny. Dokonane badania mogą stanowić dopełnienie przywołanych badań oraz stanowić inspiracje do kolejnych prac w tym obszarze badawczym.

\section{Metodologia}

Badanie miało charakter ilościowy i zrealizowane zostało na podstawie kwestionariusza ankietowego. Pytania miały charakter zamknięty. Badanie oparto na technice internetowego wywiadu kwestionariuszowego wspomaganego komputerowo CAWI (ang. Computer-Assisted Web Interview). W trakcie wypełniania ankiety respondenci samodzielnie odczytywali z ekranu treść pytań i udzielali odpowiedzi, które w czasie rzeczywistym zapisywane były na serwerze.

Udział w badaniu wzięło 400 respondentów - osób w wieku 60 lat i więcej dobranych w sposób kwotowy. Rozkład próby kontrolowano równocześnie pod względem płci, wieku i województwa zamieszkania. W badaniu wzięło udział 236 kobiet oraz 161 mężczyzn. Znacząca większość ankietowanych $(58,25 \%)$ stanowili seniorzy z średnim wykształceniem. Ankietowani reprezentowali cztery grupy wiekowe: 60-65 lat (51\%), 66-70 lat (22\%), 71-75 lat (8\%) oraz powyżej 75 lat (19\%). Rozkład próby badawczej został przedstawiony w tabeli 1.

Tabela 1: Rozkład próby badawczej względem płci, wieku i województwa zamieszkania

\begin{tabular}{|c|c|c|}
\hline Parametr & & Lącznie $(\mathrm{N}=400)$ \\
\hline \multirow{2}{*}{ Płeć } & Kobieta & $239(59,75 \%)$ \\
\hline & Mężczyzna & $161(40,25 \%)$ \\
\hline \multirow{5}{*}{ Wykształcenie } & Podstawowe & $13(3,25 \%)$ \\
\hline & Zawodowe & $56(14,00 \%)$ \\
\hline & Średnie & $233(58,25 \%)$ \\
\hline & Wyższe licencjackie/inżynierskie & $25(6,25 \%)$ \\
\hline & Wyższe magisterskie & $73(18,25 \%)$ \\
\hline \multirow{4}{*}{ Wiek } & $60-65$ lat & $204(51,00 \%)$ \\
\hline & 66-70 lat & $89(22,25 \%)$ \\
\hline & $71-75$ lat & $32(8,00 \%)$ \\
\hline & Powyżej 75 lat & $75(18,75 \%)$ \\
\hline \multirow{5}{*}{ Miejsce zamieszkania } & Wieś & $68(17,00 \%)$ \\
\hline & Miasto do 50 tys. & $104(26,00 \%)$ \\
\hline & Miasto od 50 do 100 tys. & $70(17,50 \%)$ \\
\hline & Miasto od 100 do 300 tys. & $70(17,50 \%)$ \\
\hline & Miasto powyżej 300 tys. & $88(22,00 \%)$ \\
\hline \multirow{6}{*}{ Region } & Pd-Zachodni & $43(10,75 \%)$ \\
\hline & Północny & $58(14,50 \%)$ \\
\hline & Wschodni & $70(17,50 \%)$ \\
\hline & Pn-Zachodni & $63(15,75 \%)$ \\
\hline & Centralny & $85(21,25 \%)$ \\
\hline & Południowy & $81(20,25 \%)$ \\
\hline
\end{tabular}

Źródło: Opracowanie własne.

Seniorzy w badaniu zostali zapytani o elementy: zachowania dotyczące czytania informacji zawartych na opakowaniu zewnętrznym, bezpośrednim oraz ulotce leków, elementy wpływające na trudności w odczytaniu tekstu oraz ważność poszczególnych informacji dotyczących leków.

\section{Wyniki}

Pierwszym aspektem, o który zostali zapytani starsi konsumenci odnosi się do zachowań seniorów w kontekście czytania informacji zawartych na poszczególnych rodzajach opakowania zewnętrznego oraz opakowaniu bezpośrednim i ulotki. Z badań wynika, że najwięcej informacji respondenci odczytują z opakowań zewnętrznych typu pudełko tekturowe (98,94\%) następnie tubach $(97,08 \%)$. Najmniejsza poczytność została wykazana w odniesieniu do opakowań bezpośrednich blistrów (15,38\%) następnie fiolek (9,81\%) i saszetek (9,28\%). Można zauważyć, iż informacje zawarte na opakowaniach zewnętrznych są sprawdzane przez seniorów. Wręcz przeciwny wniosek można wysnuć w stosunku do opakowań bezpośrednich (blister, fiolka, saszetka). W stosunku do ulotki ciekawym wydaje się być fakt, iż wszystkie informacje na 
niej zawarte zostają odczytywane przez ponad połowę $(50,93 \%)$ badanych. Zestawienie wyników dotyczących pytania pierwszego zostało zaprezentowane w tabeli 2.

Tabela 2: Zachowania dotyczące czytania informacji zawartych na opakowaniu zewnętrznym, bezpośrednim oraz ulotce leków

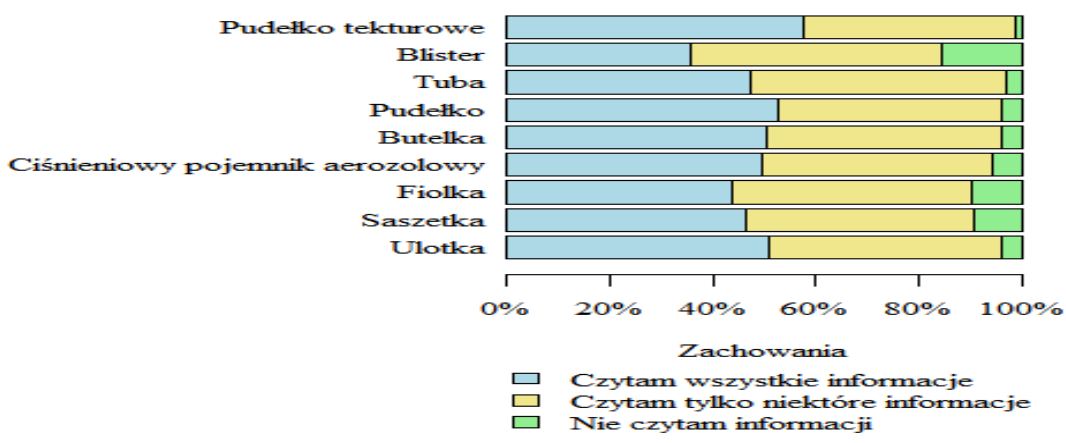

Źródło: Opracowanie własne.

Kolejne pytanie odnosiło się do identyfikacji elementów wpływających na trudności w odczytaniu tekstu przez osoby starsze. Na podstawie uzyskanych wyników można wnioskować, iż źródłem trudności w odczytaniu informacji na opakowaniu jest wielkość czcionki -62,34\% oznaczyła ten czynnik mianem dużego lub bardzo dużego wpływu, następnie kontrast barwy tła i czcionki $-44,04 \%$, grubość liter $-41,11 \%$. Najmniej istotne w procesie odczytywania informacji okazały się: dzielenie wyrazów $-25,47 \%$, długość linii tekstu $-26,79 \%$ oraz składanie ulotki $-18,57 \%$. Zestawienie wyników dotyczących pytania drugiego zostało zaprezentowane w tabeli 3.

Tabela 3: Elementy wpływające na trudności w odczytaniu tekstu

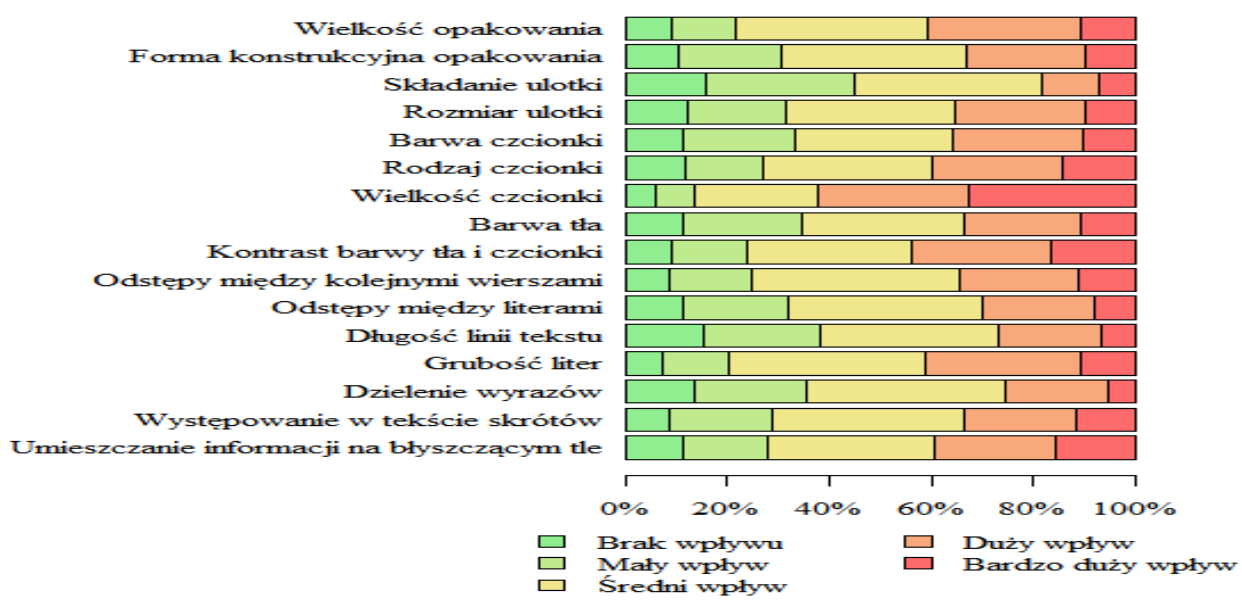

Źródło: Opracowanie własne.

Ostatnie z pytań dotyczących czytelności opakowań odnosiło się do ważności poszczególnych informacji dotyczących leków. Pośród 20 informacji i znaków zaproponowanych do oceny seniorom najważniejsze okazały się: data ważności ważna lub bardzo ważna dla 92,58\% badanych, dawkowanie - 92,84 oraz objawy przedawkowania leku - 89,66\%. Najmniej istotne z punktu widzenia respondentów są: nazwa marki $-49,87 \%$, oznaczenie partii produktu $-48,8 \%$ oraz znak towarowy $-32,36 \%$. Zestawienie wyników zaprezentowanie zostało w tabeli 4.

Tabela 4: Ważność poszczególnych informacji dotyczących leków 


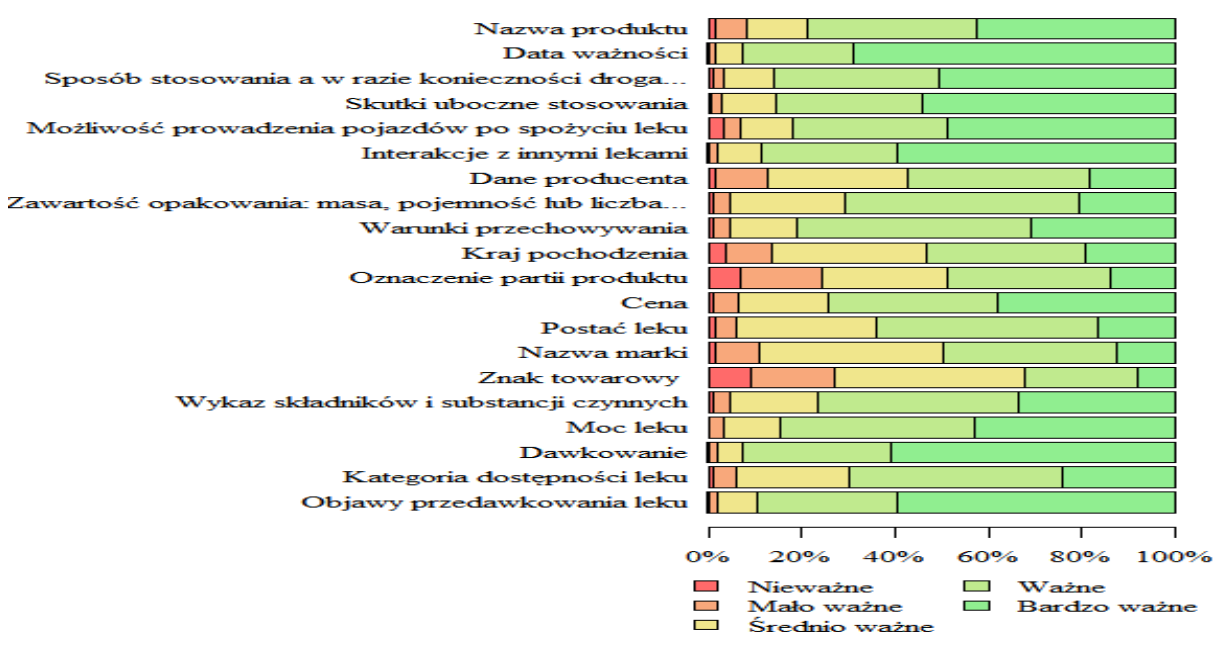

Źródło: opracowanie własne.

\section{Dyskusja}

Przedstawione wyniki badań potwierdzają ważności informacyjności opakowania dla starszych konsumentów. Seniorzy czytają informacje zamieszczone na opakowaniach. Okazuje się, że w szczególności zwracają uwagę na znaki umieszczone na opakowaniach zewnętrznych oraz ulotce. Opakowania bezpośrednie rzadko są czytane przez seniorów.

Najistotniejsze dla seniorów jest zachowanie odpowiedniej dla nich (większej) czcionki, odpowiedniego kontrastu napisów w stosunku do ich tła oraz grubość liter. Problem zbyt małej dla seniorów czcionki został już zidentyfikowany przez badaczy takich jak: Liu i in. (2014), Chubaty i in. (2009), O’sullivan i in. (2020), Da Silva i in. (2019), Lisińska-Kuśnierz i Grzybek (2019) oraz Grzybek (2020). Szczególną uwagę na konieczność zastosowania odpowiedniego kontrastu pomiędzy literami a tłem napisu zwrócił w swej pracy Chubaty i in. (2009). Kwestia wpływu grubości czcionki na czytelność informacji wydaje się być nowym kierunkiem rozważań naukowych i wymaga przeprowadzenia dalszych badań.

Przeprowadzone badania dowiodły, że kluczowymi informacjami jakich poszukują seniorzy na opakowaniu produktów leczniczych jest dawkowanie, data przydatności do spożycia oraz objawy przedawkowania leku. Elementy związane z marką produktu nie są istotne dla seniorów. Brak skupiania uwagi osób starszych na znaki związane z producentem może wynikać z faktu, iż najczęściej seniorzy decydują się na leki polecane przez farmaceutów/lekarzy.

\section{Bibliografia}

1. Byłeń S. (2016). Nowe trendy marketingowe w opakowalnictwie, (w:) "Przedsiębiorczość i zarządzanie" tom XVII, Zeszyt 9, Część III, 101-117.

2. Caban-Piaskowska K., Miarka A. (2018). Starzenie się społeczeństwa szansą rozwoju przedsiębiorstw (w:). Handel wewnętrzny, 6(377), 110-120.

3. Chubaty A., Sadowski Ch., Carrie A. (2009). Typeface legibility of patient information leaflets intended for community-dwelling seniors (w:). Age and Ageing, 38(4), 441-447. https://doi.org/10.1093/ageing/afp065

4. Cybulski, M., Cybulski, L., Krajewska-Kulak, E., Orzechowska, M., Cwalina, U. (2018). Preferences and attitudes of older adults of Bialystok, Poland toward the use of over-the-counter drugs (w:). Clinical Interventions in Aging, Nr 13/2018, 623-632. https://doi.org/10.2147/CIA.S158501

5. Da Silva Pons, E., Moraes, C.G., Falavigna, M., (...), Webster, G., da Silva Dal Pizzol, T. (2019). Users' preferences and perceptions of the comprehensibility and readability of medication labels (w:). PLoS ONE, Nr 14(2). e0212173. https://doi.org/10.1371/journal.pone.0212173

6. Droulers O., Amar J. (2016). The legibility of food package information in France: an equal challenge for young and elderly consumers? Public Health Nutrition, 19, 1059-1066. https://doi.org/10.1017/S1368980015002141

7. Fraeyman, J., Peeters, L., Van Hal, G., De Meyer, G.R.Y., De Loof, H. (2015). Consumer choice between common generic and brand medicines in a country with a small generic market. Journal of Managed Care Pharmacy, 21(4), p. 288-296. https://doi.org/10.18553/jmcp.2015.21.4.288

8. Grzybek K. (2020). Ocena stopnia zadowolenia starszych konsumentów z użytkowania opakowań produktów leczniczych dostępnych bez recepty, Zarządzanie i logistyka w XXI wieku. Kierunki rozwoju, pod. red. A. Krzysztofek, wyd. ArchaeGraph, Łódź-Kielce, p. 39-50.

9. Isaacs T., Murdoch J., Demijen Z., Stevenson F. (2020). Examining the language demands of informed consent documents in patient recruitment to cancer trials using tools from corpus and computational linguistics, Health. An Interdisciplinary Journal for the Social Study of Health, Illness and Medicine, 13. https://doi.org/10.1177/1363459320963431

10. Karapinar-Çarkit, F., van den Bemt, P.M.L.A., Sadik, M., (...), van Hunsel, F., van Riet-Nales, D.A. (2020). Opportunities for changes in the drug product design to enhance medication safety in older people: Evaluation of a national public portal for medication incidents. British Journal of Clinical Pharmacology, 86(10)/2020, 19461957. https://doi.org/10.1111/bcp.14392 
11. Liu F., Abdul-Hussain S., Mahboob S., Rai V., Kostrzewski A. (2014). How useful are medication patient information leaflets to older adults? A content, readability and layout analysis. International Journal of Clinical Pharmacy. 36. https://doi.org/10.1007/s11096-014-9973-2

12. Louw, A. (2006). The Power of Packaging, USA. 186-216.

13. Lisińska-Kuśnierz M., Grzybek K. (2019). Użyteczność opakowań produktów leczniczych z punktu widzenia potrzeb starszych osób, Towaroznawstwo w badaniach i praktyce - Jakość produktów przemysłowych -wybrane aspekty, pod. red. J. Szakiel, P. Turek, wyd. Sieć Badawcza Łukasiewicz - Instytut Technologii Eksploatacji, Radom.

14. Mamen, AV., Hakonsen, H., Kjome, RLS., Gustavsen-Krabbesund, B., Toverud, EL. (2015). Norwegian elderly patients' need for drug information and attitudes towards medication use reviews in community pharmacies. International journal of pharmacy practice, 23/2015, 423-428. https://doi.org/10.1111/ijpp.12184

15. Niezgoda A., Jerzyk E. (2013). Seniorzy w przyszłości na przykładzie rynku turystycznego (w:) Marketing przyszłości. Trendy. Strategie. Instrumenty. Konsument jako uczestnik procesów rynkowych i odbiorca komunikatów marketingowych, red. G. Rosa, A. Smalec, Zeszyty Naukowe Uniwersytetu Szczecińskiego, nr 777, Problemy zarządzania, finansów i marketingu, nr 32.

16. Oeser, G., Aygun, T., Balan, C.L., Paffrath, R., Schuckel, M.T.(2019). Segmenting elder German grocery shoppers based on shopping motivations. Int. J. Retail. Distrib. Manag., 47, $129-156$. https://doi.org/10.1108/IJRDM-02-2018-0033

17. O'Sullivan L, Sukumar P, Crowley R, et al. (2020), Readability and understandability of clinical research patient information leaflets and consent forms in Ireland and the UK: a retrospective quantitative analysis. BMJ Open 2020(10), e037994. https://doi.org/10.1136/bmjopen-2020-037994

18. Pradeep A.K. (2011). Mózg na zakupach. Neuromarketing w sprzedaży, Wydawnictwo Helion, Gliwice.

19. Rajska-Neumann A., Wieczorowska-Tobis K., Mossakowsska M., Skalska A., Ślusarczyk P., Świech M., Grodzicki T., (2012). Farmakoterapia u osób starszych w Polsce, Polsenior, Aspekty medyczne, psychologiczne, socjologiczne i ekonomiczne starzenia się ludzi w Polsce, pod red. Mossakowska M., Więcek A., Błędowski P., Temdia Wydawnictwa Medyczne, Poznań, 379-393.

20. Raport Narodowego Funduszu Zdrowia (2020). NFZ o Polipragmazji.

21. Stroud D. (2005). The 50-plus market: Why the future is age neutral when it comes to marketing \& branding strategies. London: Kogan Page.

22. Szepieniec-Puchalska D., Szymańska A., (2016). Senior Consumers' Attitudes Towards Innovative Products. Problemy zarządzania - management issues, 14(2(59)), 185-203 https://doi.org/10.7172/1644-9584.59.12

23. Śmiechowska M., Wawszczak S.(2010). Etykieta jako element wizualizacji marki [w:] Zarządzanie produktem. /kreowanie marki, red. J.Kall, B. Sojkin. Zeszyty Naukowe Uniwersytetu Ekonomicznego w Poznaniu, 154, 120127.

24. Świda J, Migała-Warchol A. (2016). Ograniczenia funkcji komunikacyjnej opakowań produktów spożywczych użytkowanych przez starszych konsumentów. Modern management review, XXI(3), $183-197$. https://doi.org/10.7862/rz.2016.mmr.34

25. Świtała M. (2011), Zachowania konsumpcyjne ludzi w wieku starszym, Wydawnictwo Uniwersytetu Ekonomicznego w Katowicach, Katowice.

26. Ustawa z dn. 6 września 2001 r., Prawo farmaceutyczne, Dz. U. 2001 Nr 126 poz. 1381 z późniejszymi zmianami. 